\title{
MarX’s Hegelian Critique of Hegel
}

Tony Smith ${ }^{1}$

(Iowa State University)

\section{Hegel's Defense of Capitalist Market Systems}

The system of needs is Hegel's term for the modern capitalist economy, a system of generalized commodity production and exchange. ${ }^{2}$ A person generally wants to own a particular commodity because its particular concrete (qualitative, heterogeneous) properties enable it to address a particular concrete (qualitative, heterogenous) need. ${ }^{3}$ There may be other needs the same object can address as well. Or other things may be able to address the same need. Such considerations led Hegel to assert that a higher-order universal concept, need in general, is implicit whenever particular needs are addressed by particular things. Similarly, we can consider the general usefulness of an object, that is, its ability to address need in general to some extent or other. Hegel terms this abstract (quantitative, homogeneous) property the value of the object:

A thing in use is an individual thing ... related to a specific need. ... (T)he specific need which it satisfies is at the same time need in general

1 tonys@iastate.edu The author would like to thank Dan Krier, Geert Reuten, and the Organizing Committee of the Lisbon Hegel/Marx conference for helpful comments on an earlier draft of this article.

2 Hegel argues that a well-functioning market society requires the administration of justice, an impartial judicial system with coercive powers capable of effectively enforcing property and contract rights. Its effective operation will be assumed here.

3 Throughout the paper "needs" is to be taken in Hegel's very broad sense, including the "wants" often contrasted to the "basic needs" of biological organisms.

Philosophica, 54, Lisboa, 2019, pp. 11-32. 
and thus is comparable ... with other needs, while the thing in virtue of the same considerations is comparable with things meeting other needs. This, the thing's universality ... abstracted from the thing's specific quality, is the thing's value (Hegel 2008, pp. 74-5/§63).

This value is then expressed in abstract (quantitative, homogenous) units of money:

(I)f you want to express the value of a thing not in its specificity but in the abstract, then it is money which expresses this. ... Money, as something abstract, merely expresses this value (Ibid., p. 75/\$63 Addition).

The category system of needs captures Hegel's view of the capitalist economy perfectly. From his standpoint the paradigmatic sequence of economic actions begins with someone owning a particular commodity $\left(\mathrm{C}_{1}\right)$ not needed much, if at all. If it is sold at its value the money $(\mathrm{M})$ obtained can then be used to purchase a different commodity $\left(\mathrm{C}_{2}\right)$ with the same value but different particular properties that enable the particular needs of the buyer to be addressed to a greater degree than was the case before the exchanges. ${ }^{4}$ Both commodities and money are thereby essentially means to address human needs.

Of course, in the endless series of exchanges...C-M-C-M-C-M-C-M$C-M-C \ldots$ it is as easy to discern a M-C-M pattern as C-M-C sequences. $\mathrm{M}-\mathrm{C}-\mathrm{M}$ " circuits are more to the point; no one would dispute that many economic agents in capitalism are profit-driven, aiming at a monetary return (M') exceeding their investments (M). In Hegel's account, however, money is only ever a proximate goal, sought today so that goods and services addressing needs can be purchased tomorrow.

For Hegel, this system of needs is a realm of freedom. In contrast to social formations based on slavery, serfdom, forced tribute, or bureaucratic commands, individuals are free to pursue their own particular conceptions of the good, so long as those conceptions do not involve infringing the rights of others to do the same. Freedom of consumer choice and freedom of occupation are two important corollaries. Further, the spur market societies give to the development of new needs and new capabilities frees their members from both the limits of "natural" biological needs and constraints imposed by traditional social practices.

4 The fact that some commodities - raw materials, tools, etc. - contribute to addressing human needs indirectly complicates the picture without changing anything essential. 
Hegel also argues that the system of needs institutionalizes an unprecedented general level of material well-being. Most economic agents do not intend their actions to further the general good. But as Adam Smith famously put it, the logic of market competition operates as an "invisible hand," ensuring that the aggregate good of society is furthered behind their backs. Individuals' private self-interest in market success is most likely to be fulfilled when their economic activity contributes to the production and distribution of commodities that help others address their needs.

Surprisingly, perhaps, Marx agreed with much of this. Throughout his life Marx vehemently dismissed attempts to romanticize pre-capitalist societies. He recognized that the freedom granted in modern market societies (in principle, if hardly always in practice) was an advance over slavery and serfdom (Marx 1986a, p. 213). And he granted that no other mode of production has brought greater productivity advances or higher general living standards than capitalism. Of course, for Marx this is only one side of the story. The same, however, can be said of Hegel.

No less than Marx, Hegel explicitly notes systematic tendencies to market failure with respect to the provision of public goods, and the safety of food and other products. Hegel too saw that the "invisible hand" does not prevent involuntary unemployment, severe inequality, extreme poverty, and pervasive economic insecurity. He noted how market societies are beset by a systematic tendency to produce more goods and services than markets can absorb ("overproduction"), with the resulting bankruptcies imposing great hardship on workers and their communities (Hegel 2008, p. 222/§245). The same harms occur when imports capture domestic markets. Hegel's critique goes deeper still when he emphasizes how market imperatives are imposed on individual agents with external necessity. Individuals cannot be "at home" in a world governed by the alien power of market forces, even if those forces are nothing but the aggregate results of their own free choices (Ibid., p. 184/§186).

At this point, however, Hegel and Marx take different paths. In Hegel's methodological framework the systematic shortcomings of one level of determinations provide justification for a transition to a higher level. In the case at hand, the critical shortcomings of the system of needs establish the systematic necessity of moving to higher-order determinations of the rational modern polity, including

* A Public Authority ("Police") charged with providing public goods and regulating businesses in the public interest); 
* Voluntary and Municipal associations in civil society ("Corporations") insuring members against sickness, old age, and involuntary unemployment, provide retraining for displaced workers, and so on.

* Government agencies on local, regional, and national levels actively supporting economic development, nurturing industries with advantages in the world market and emerging sectors capable of replacing those in decline.

* State agencies effectively implementing social welfare programs providing a safety net for those in the direst circumstances.

Most importantly of all, The Philosophy of Right culminates with a constitutional republic, including

* An extensive public sphere engaged in on-going discussion of matters of public concern.

* Legislative bodies with representatives from all significant social groups, accountable to those they represent and capable of coming to agreement on laws warranting rational assent.

* An administrative apparatus with relevant expertise to implement laws and institute supplementary regulations when necessary.

* A top state official with responsibility for oversight of domestic programs and foreign policy (while itself subject to effective oversight by the legislature and citizenry).

A strong argument can be made that the rational state forms the polity as a whole into a "concrete universal," mediating individuality, particularity, and universality together in a rational dynamic system:

(I)n the practical sphere the state is a system of three syllogisms. (1) The Individual or person, through his particularity or physical or mental needs (which when carried out to their full development give civil society), is coupled with the universal, i.e. with society, law, right, government. (2) The will or action of the individuals is the intermediating force which procures for these needs satisfaction in society, in law, etc., and which gives to society, 
law, etc., their fulfillment and actualization. (3) But the universal, that is to say the state, government, and law, is the permanent underlying mean in which the individuals and their satisfaction have and receive their fulfilled reality, intermediation, and persistence (Hegel 1975, pp. 264-5/§198; see Vieweg 2012).

Assertions regarding the whole can only be legitimately made on the level of the whole. From a Hegelian perspective, however, Marx's criticisms of modern society as a whole apply at most to the economy taken in abstraction from the whole. A Hegelian would say that Marx failed to recognize that the higher-order political framework of the state is capable in principle of putting the most pernicious tendencies in markets out of play.

This is not how Marx would formulate the dispute.

\section{Marx's Concepts of Value and Capital}

For Hegel, a useful thing has both concrete properties enabling it to meet concrete human needs and an abstract property, value, its general utility in meeting needs in general. In every human society that has ever existed, particular things have been used to address particular needs. If general utility and need in general are implicit in the relationship of using things, "value" would be an objective property of things in any and all societies. This transhistorical concept of value does not contribute to the goal Hegel and Marx shared of comprehending our time in thought.

If we want a concept of value specific to modern capitalism, we must begin with historically specific features of its essential social relations. When products take the social form of commodities produced for sale, they come with the risk of not being sold. If other producers seize the market, or buyers cannot be found, the production has been socially wasted. Producers in previous societies generally did not have to worry about this. They knew ex ante that if food were grown, it would be eaten; if clothes were sown, they would be worn. But in generalized commodity production producers are separated both from each other and from the ultimate users of their products. Sociality here takes the historically specific form of dissociated sociality.

If the social relationships among producers and users cannot be not guaranteed ex ante, they must be established ex post. The social validation of privately undertaken production occurs when products are sold for money. Only then do they objectively possess social value. "Value" in this 
sense is an abstract (quantitative, homogenous) property ("produced by a certain amount of socially validated private labor"). ${ }^{5}$ But unlike Hegel's concept of value, this concept is a real abstraction, brought about by an actual social process specific to modern capitalism.

Marx agrees with Hegel that value is essentially connected to needs. (In his terminology, a commodity cannot have value if it lacks use value.) The essential matter, however, is that when social relationships are in the form of dissociated sociality, these relationships necessarily appear in the form of properties of things (the values of commodities, represented in money). Marx refers to this as the "fetish character" of commodities and money. For Marx, the modern capitalist economy is more a system of fetishism than a system of needs. When Marx writes in one of the Grundrisse's most striking formulations that each individual "carries his social power, as also his connection with society, in his pocket," we are meant to take this statement literally (Marx 1986a, p. 94).

For Hegel, commodities and money are essentially means to further human ends, even if money can be a proximate end of economic activity. For Marx, in contrast, when human sociality takes the form of dissociated sociality means and ends become inverted. This is indisputably the case for units of production and distribution:

* The sale of commodities for money is the only way privately undertaken production can be socially validated. Units of production and distribution must make sale for money the overriding end of their endeavors in any given period or lose their investment.

* This compulsion in reinforced when we consider the competitive pressures facing units of production and distribution over time. If they hope to survive, they must obtain monetary resources in a given period if they are to purchase the commodity inputs required in the next period.

* These units must in fact strive to obtain monetary returns exceeding initial investment. If they begin a new cycle with a significant lower amount of investment funds than their competitors, they would necessarily tend to be in a disadvantageous position. Competitors would be better able to expand production,

5 Since the money in which this value is expressed can in the proper amounts be used to purchase any commodity, "value" can also be defined as the abstract property "generalized exchangeability." 
invest in more advanced productive inputs, increase marketing expenditures, develop promising new product lines, respond to new market opportunities, meet unexpected market fluctuations, retain old investors, attract new ones, and so on.

It follows that units of production and distribution that do not systematically direct their endeavors to the appropriation of monetary returns $\left(\mathrm{M}^{\prime}\right)$ exceeding initial investment $(\mathrm{M})$, tend to be pushed to the margins of social life, when not forced out of existence altogether. They must therefore systematically subordinate other ends to the pursuit of monetary returns. Marx's conclusion regarding units of production and distribution in generalized commodity production is unequivocal: "Use-values must therefore never be treated as the immediate aim ... nor must the profit on any single transaction. [The] aim is rather the unceasing movement of profit-making" (Marx 1976, p. 254).

What of the social agents who consume commodities because of their use-value in addressing their needs? Here too need satisfaction is hardly the whole story.

* The goods and services required to address human needs generally take the form of commodities owned by others who demand money for them. Where does this money come from? In general, individuals must acquire it through association with units of production or distribution whose "aim is ... the unceasing movement of profit-making." Whatever form this takes - working for a wage or salary, owing stocks and bonds, being a member of a household where those forms of income are shared - the ability of social agents to meet their human needs generally depends on whether the units of production and distribution with which they are associated attain the inhuman end of a M' exceeding M. In this sense the latter has objective priority over the former.

* Human needs addressed within generalized commodity production and exchange are systematically restricted to those that can be addressed by goods or services in the form of commodities. This is a subset of all needs. Further, only those needs that have sufficient purchasing power ("effective demand") behind them are addressed. The needs relevant to the so-called system of needs are therefore limited to a subset of a subset of needs. The valorization 
imperative ("M must become $\mathrm{M}$ '!") imposes this restriction, further evidence of its objective priority.

* When individual agents purchase goods and services for consumption, their subjective intention is simply to address their needs. But the objective social meaning of their actions goes beyond that intention. Their purchases socially validate the privately undertaken endeavors of units of production and distribution. In other words, the culminating $\mathrm{M}-\mathrm{C}$ phase of a C-M-C sequence is incorporated within a M-C-M'circuit, contributing to its culminating moment, C-M'.

* After a purchase for the sake of consumption has been completed, agents whose needs have been addressed now have fewer monetary resources. In a world where money is generally required to gain access to the means to satisfy needs, their funds must eventually be replenished. And that process, once again, presupposes renewed association with circuits that have money as their endpoint.

* Finally, if we consider C-M-C and M-C-M' sequences together an important asymmetry is manifest. A given $\mathrm{C}-\mathrm{M}-\mathrm{C}$ series ends with the consumption of a product; a successful $M-C-M$ 'sequence does not end. It is reproduced and expands over time; the $\mathrm{M}^{\prime}$ that is the culmination of one sequence serves in whole or in part as the $\mathrm{M}$ of a subsequent sequence. In social reproduction as a totality, then, C-M-C exchanges lack the substantiality of M-C-M'circuits.

To speak of a M-C-M' circuit reproducing and expanding over time is to say that value maintains its identity as it proceeds from the form of money to that of commodities and back again:

$[\mathrm{B}]$ oth the money and the commodity function only as different modes of existence of value itself ... [Value] is constantly changing from one form into the other, without becoming lost in this movement; it thus becomes transformed into an automatic subject ... [V]alue is here the subject of a process ... (T)he movement in the course of which it adds surplus-value is its own movement, its valorisation is therefore self-valorisation... [V]alue suddenly presents itself as a self-moving substance which passes through a process of its own, and for which commodities and money are both mere forms (Ibid., pp. 255-6). 
"Capital" is Marx's term for this value in process. Taking into account phases of the process left implicit to this point, capital first takes on the form of investment capital (M) used to purchase inputs into production (commodity capital C), followed by the phase of capital in production $(\mathrm{P})$, which results in commodity outputs $\left(\mathrm{C}^{\prime}\right.$, inventory capital) that are then sold for a monetary amount exceeding the initial investment $\left(\mathrm{M}^{\prime}\right.$, realized capital).

Marx's concept of capital, no less than Hegel's system of needs, concerns production and distribution as a system. All the interacting circuits of capital together form a macro-monetary circuit on the level of the society as a whole, beginning with the aggregate amount of money capital initially invested in the society in a given period, progressing through the aggregate production and circulation of commodities in that period, and finally culminating with the aggregate returns from sale of these commodities.

Marx's concept of capital as a macro-monetary totality is a profoundly original contribution to social ontology. "Capital" is missing in Hegel's Philosophy of Right. That is like Hamlet without the Prince. To categorize the modern market economy as a system of needs is to miscategorize it; it is essentially a system of capital. Its ultimate purpose is not the satisfaction of human needs, but the furthering of capital's insatiable need for valorization, the transformation of M into M'. Its ultimate good is not a human good, but capital's good. The alienation here goes far beyond individuals' external relationship to the aggregate consequences of their individual choices, as Marx's discussion of the capital/wage labor relationship makes clear.

\section{The Capital/Wage Labor Relation}

For Hegel (and many others) the wage labor contract is in principle a free agreement among equally free agents. In this case, however, one party does not simply agree to give up a thing to another in return for some other thing. One person agrees to put the use of his or her human capabilities at the disposal of another. Since for Hegel persons are nothing more than their actions and the reverberations of those actions in history, this might seem to be in tension with a fundamental principle of abstract right: persons can exchange things, but are not themselves objects to be exchanged. The freedom of persons to exchange objects does not extend to a freedom to sell ourselves into slavery. ${ }^{6}$ To alleviate this worry, Hegel asserts that

6 "By alienating the whole of my time, as crystallized in my work, and everything I produced, I would be making into another's property the substance of my being, my universal activity, my personality" (Hegel 2008, pp. 78-9/\$67). 
having property in a thing implies the right to full use of that thing (Hegel 2008, p. $73 / \S 62$ ). In the wage contract the activities of the laborer are put at the disposal of the employer for a limited period of time. Since full use is absent, the wage laborer retains the status of an autonomous person (Ibid., pp. 78-9/§67).

This argument must be considered as one of the weakest in the Hegelian corpus. For one thing, the time wage laborers are subject to capital is still substantial enough to be a matter of normative concern. ${ }^{7}$ Other difficulties will become apparent after considering Marx's claim that the systematic reproduction of the macro-monetary circuit of capital $\left(M-C-P-C^{\prime}-M^{\prime}\right)$ is simultaneously a systematic reproduction of the capital/ wage labor relationship.

In capitalist market societies a relatively small group owns and controls a critical mass of investment capital (M), enabling them to purchase the commodity inputs required for production and distribution (C). Some of these commodities are means of production (raw materials, tools and machinery, and so on), purchased from some units of capital by other units. Of more relevance here is the purchase of a quite different sort of commodity. Those who do not have a critical mass of monetary holdings are "dissociated" from the objective material preconditions of human life. Means of human subsistence, and the means of production necessary to produce those means of subsistence, both take the social form of commodities owned by others. Non-owners must somehow obtain money to gain access to the goods and services they and their dependents need. This means in effect that they must sell their labor power as a commodity to those who own and control investment capital. Their living labor is then set to work in a production process $(\mathrm{P})$, resulting in a set of commodity outputs (C'). If all goes well these commodities can then be sold profitably for some monetary return (M') exceeding initial investment.

The aggregate commodity outputs include wage goods. After wages

7 Consider a wage laborer who spends 9 hours at a workplace, 2 hours in transit to and from the workplace, an hour preparing for the workday, another recovering from it physically and psychologically, a further 3 hours engaged in tasks required for the labor of this person and any dependents to be available for hire in the future (shopping, cooking, eating, cleaning, etc.), and sleeping 8 hours. That would be all 24 hours in the day of one's person's life directly connected to employment as a means for others' gain. If this person were to carve out a little time of their own, how much of a substantive difference would that really make? I note in passing that capital's colonization of leisure time is one of the distinguishing features of contemporary capitalism, whether through commodified spectacles or through the commodification and monetarization of information we reveal about ourselves in activities outside the workplace. 
have been spent on purchasing them (with perhaps a small amount set aside for savings), workers find themselves at the start of the next macro-monetary circuit, once more without extensive monetary reserves. They must therefore once again sell their labor power as a commodity to those who own and control investment capital. The owners and controllers of capital, in contrast, have as a group (if not in each case) obtained a monetary return enabling them to reinvest in the following circuit, even after (typically extensive) funds have been deducted for their personal consumption. From the standpoint of both wage labor and capital, then, the process of capital's valorization is simultaneously a process reproducing the capital/wage labor relation.

In Marx's account three essential features of this process are of special significance.

1. In generalized commodity production and exchange wage laborers are free to seek employment from whomever they wish. In principle, at least, no direct personal coercion underlies labor contracts. But coercion can be indirect and impersonal. In a monetized economy, those lacking sufficient money capital are generally forced to sell their labor power to some unit of capital or other. This is a structural coercion, due to the social forms in place, rather than the natural conditions of human life.

2. Whenever labor processes involve extensive social cooperation, there will be a need for decisions to be made regarding who is to do what, when they are to do it, and with whom it is to be done. In capitalist market societies, the social power to make these decisions ultimately lies with owners/investors and the managers they appoint to represent their interests. Those exercising this authority in workplace communities are not accountable to those over whom the authority is exercised. This is a form of social domination.

3. All societies in human history must produce social wealth and a social surplus, that is, goods and services exceeding what producers use to reproduce themselves over time. In capitalist market societies the social surplus takes the historically specific form of surplus value, the difference between M' and M. Wage laborers will be hired if and only if the owners and controllers of capital foresee that at the completion of the capital circuit surplus value will have been produced that investors are able to appropriate and allocate as their private property. The wage laborers who collectively produced this surplus (with the aid of machinery and other goods previously produced by other wage laborers, the gifts of nature, the collective knowledge of the commons, and so on) have no more control over its allocation than slaves or serfs had over the social surplus they 
produced for their masters and lords. In this crucial sense of the term wage laborers are exploited. "Capital ... valorises itself through the appropriation of alien labour" (Marx 1986a, p. 233).

The Hegelian category Schein refers to appearances that are at once necessary manifestations of essential matters and illusionary distortions of them. Hegel uses the term to refer to the illusion of individual agents in market societies that their well-being depends on their own free actions, blind to the way their freedom and well-being presupposes the entire institutional framework of the modern polity (Hegel 2008, p. $180 / \S 181$ Addition). For Marx, Schein is indeed an appropriate category here. But for him the illusions are much deeper than Hegel recognized. It is mere Schein when this system appears to essentially be about human needs, rather than capital's valorization. And the surface appearance of a system of free transactions among formally equal individuals occludes the heart of the matter: the systematic reproduction of a relationship essentially involving structural coercion, social domination, and social exploitation:

It is [not] a mere accident that capitalist and worker confront each other in the market as buyer and seller. It is the alternating rhythm of the process itself which throws the worker back onto the market again and again as a seller of his labour-power and continually transforms his own product into a means by which another can purchase him. In reality, the worker belongs to capital before he has sold himself to the capitalist. His economic bondage is at once mediated through, and concealed by, the periodic renewal of the act by which he sells himself, his change of masters, and the oscillations in the market-price of his labour (Marx 1976, p. 724).

Marx conclusion echoes Hegel's assessment of slavery's historical limits:

The recognition of the product as its [the laborer's] own, and its awareness that its separation from the conditions of its realisation is an injustice - a relationship imposed by force - is an enormous consciousness, itself the product of the capitalist mode of production and just as much the KNELL TO ITS DOOM as the consciousness of the slave that he could not be the property of another reduced slavery to an artificial, lingering existence, and made it impossible for it to continue to provide the basis of production (Marx 1986a, pp. 390-1). 
Hegelians reject this conclusion, arguing that Marx's "economism" prevented him from recognizing how problems in the capitalist economy can be addressed by higher-order institutions, especially the state. A Marxian response to this charge follows.

\section{Marx on the Political}

The three volumes of Capital represent only the first "Book" in the system of essential determinations of the capitalism projected by Marx (Ibid., p. 45; Smith 1990, pp. 200-5). His call for a separate "Book on the State" shows that he recognized that comprehending the state requires more complex and concrete determinations than those considered in Capital. We should also recall that in Marx's historical writings, political essays, and journalist reports he regularly stressed the causal role state officials have played in capitalism's development. And in Capital itself Marx wrote at length about an ultimately successful struggle for reform legislation limiting the length of the working day.

This leads to an obvious question. If Hegel says that the state is capable of independent action and of instituting reforms checking pernicious tendencies in the capitalist economy, how could Marx disagree, when he himself showed that the state is no mere epiphenomenon and he himself devoted so many pages of his masterwork to a successful reform? The answer lies with the historically specific form of "the political" in modern capitalist societies.

In pre-capitalist class societies the political nature of the dominant social relations was reasonably transparent. On the one side there were slave owners; on the other slaves, producing a surplus appropriated by masters, or serfs producing a social surplus appropriated by lords. In yet other contexts warrior elites demanded tribute from independent peasant households. In all these cases, appropriating the social surplus was an essential part of political domination. In pre-capitalist societies there was no distinct "economic" sphere separate from a "political" realm.

In capitalist market societies matters appear quite different. The production and distribution of goods and services is mediated by the formally free decisions of individual persons to exchange commodities and money. State officials provide the background conditions for these choices (minimal for classical liberals; extensive for Hegel) and then step aside. Within this framework the obvious separation of "economic" and "political" spheres appears obvious. 
Marx insists that this appearance is illusionary. Once the social relations of dissociated sociality are in place - the separation of producers from each other and from buyers, and the separation of individuals from the material preconditions of human existence - then the political community as a whole will be subjected to the valorization imperative and structured by a division between a surplus producing class and a surplus appropriating class. These are inherently political matters. To consider them as simply results of individual free choices is to be lost in Schein. Far from being guilty of "economism," Marx is the great theorist of the extension of political considerations to their proper full scope. Capitalist society - and Hegel's systematic reconstruction of its essential determinations - rests on the fundamental category mistake of depoliticizing what is inherently political.

The other side of the coin of the depoliticization of "the economic" is the impoverishment of what is categorized as "political" in modern capitalism. The most fundamental questions of political life - What is the ultimate goal of our society? What sort of social relationships should structure the political community? - are treated as if they have not already been substantially answered by the valorization imperative and the reproduction of the capital/wage labor relation, respectively.

Markets can and must be effectively regulated by the state. But political reforms addressing the pernicious structural tendencies of the capitalist economy must always be partial and precarious, due to its depolitization of inherently political matters, and the corresponding impoverishment of politics (Smith 2017). The important question here is whether these limits rule out the concrete universality Hegel claims for the modern state in the passage quoted at the conclusion of section 1. A number of considerations justify concluding that this is indeed the case.

\section{The Illusory Promise of "Civic Republicanism"}

Leading Hegelian scholars rightly assert that Hegel was committed to a strong form of "civic republicanism" (Westphal 2018). But,

* No political system leaving untouched the subordination of one class to another in the production of a social surplus can adequately institutionalize such an order. Those controlling a critical mass of capital exercise an authority in workplace communities, and over the allocation of the social surplus in the polity as a whole, that is not subject to the consent of those over whom it is exerted. 
* No political system leaving the allocation of the social surplus produced in the society as a whole to the private decisions of a relative handful of powerful citizens can adequately institutionalize strong civic republicanism.

* No political system incorporating class inequality can institutionalize the substantial equality of political citizenship demanded by strong civic republicanism. The direct funding of political candidates, the ownership of media used to transmit political messages, the support of think tanks promulgating favored ideas, are only the most overt weapons granting those owning and controlling critical masses of capital wildly disproportionate political weight. Control of investment funds is itself a powerful political weapon. If a constitutional republic were to institute policies threatening to significantly shift the balance of power between labor and capital in the former's favor, a capital strike would be inaugurated, plunging the economy into chaos. Faced with a refusal to invest, state officials would then face a stark choice: either rescind the reforms unacceptable to the representatives of capital or inaugurate a break from the property relations granting their private interests a de facto veto over public policy. Either option undermines the Hegelian claim that the polity of a capitalist market society can attain a true "concrete universality" harmoniously uniting universal law and government, the satisfaction of the particular needs of society, and the flourishing of individuals.

\section{The Limitations of Environmental Politics}

All systems of producing and distributing goods and services use natural resources and generate wastes. But capitalism's unrelenting "Grow or die!" imperative accelerates these processes into hyperdrive. Capitalist firms must attempt to appropriate as much profit as possible as fast as possible by producing, transporting, and selling as many commodities as possible, as fast as possible. This hyper-accelerated temporality inevitably comes into tension with the temporality of replenishing natural resources and processing wastes. Natural resources tend to be extracted at a much faster rate than ecosystems can replenish them, and wastes tend to be generated at a much faster rate than ecosystems can absorb them. Eventually, a tipping point will be reached past which the degeneration of natural conditions exceeds the planetary boundaries within which human 
history has unfolded (Marx 1976, p. 638). This catastrophe can be avoided only if the valorization imperative is dismantled. That is beyond the remit of any political order committed to maintaining a capitalist market society.

\section{The Competitive State vs. The Social State}

The state form Hegel advocates is actually a combination of two distinguishable state forms. In response to the tendencies to involuntary unemployment, economic insecurity, and economic crises in modern capitalism, Hegel advocates a strong competition state, capable of fostering economic development in new dynamic sectors of the domestic market and in domestic firms promising to be successful in foreign markets (Hegel 2008, p. 217/§236). In response to these tendencies and the severe inequality and poverty markets tend to generate Hegel calls for a social state ensuring the well-being of all individuals is met to the greatest feasible extent (Ibid., p. 220/\$242). A successful competition state requires extensive public investments in infrastructure, as well as extensive support for a national innovation system capable of generating a continuing stream of commercializable innovations (basic research, long-term R\&D, support for start-ups, procurement of high-tech products, etc.) and taxation policies encouraging high levels of private investment. An adequate social state ensuring that all citizens have access to the material preconditions for human flourishing also demands considerable state funding, along with an aggressively redistributive tax scheme. The relationship between the competition state and the social state is asymmetrical: the availability of the funds required by the social state presupposes the success of the competition state in fostering social wealth in the national economy. There may be moments - golden ages of capitalist development - when particular regions enjoyed considerable competitive advantages in the world market and were so confident of maintaining them that ample funds were made available for the tasks of the social state. But in a world market subject to the valorization imperative that situation necessarily tends to be temporary. Eventually a trade-off must be made between the demands of the competition state Hegel endorses in the Philosophy of Right and the requirement of the social state he also calls for. In the face of competitive pressures and the constant threat of an investment strike, societies under the reign of capital necessarily tend to grant priority to state spending and tax policies fostering profit interests (Kalecki 1971). As long as the national economy remains a subordinate moment within the capitalist world market, the social state can at most be incorporated as a subordinate moment of the 
competitive state, falling short of the extensive scope called for by Hegel.

\section{Uneven Development in the World Market}

Even a subordinate form of social state cannot be generalized on the level of the interstate system, due to the systematic tendency towards uneven development in the capitalist world market. Establishing and maintaining an effective national innovation system is very expensive. Wealthy regions are able to afford the costs of the innovation necessary for success in the world market. Poor regions, in contrast, are trapped in a vicious circle: the inability to fund innovations today undermines the attempt to obtain the wealth to fund innovations tomorrow. Only a handful of countries have broken out of this vicious circle in recent centuries, thanks to contingencies that cannot be generalized. The "rules of the game" enable wealthy regions to reproduce and exacerbate their advantages over time, making the persistence of severe global inequality and poverty an essential determination of global capitalism, ruling out the universalization of the social state across the globe (Smith 2005, Chapter 5).

\section{A New Moment in World History}

In absolute terms, as just noted, only a handful of regions across the globe have been able to establish effective national innovation systems. In relative terms, however, an unprecedented number now operate. In 2016 the U.S. share of total global R\&D funding was $26.4 \%$. Europe funded another one fifth of total global R\&D. Asia's share reached $41.8 \%$, with China accounting for $20.4 \%$ (R\&D Magazine 2016, p. 3).

The proliferation of national innovation systems is a positive development as far as the rates of innovation and diffusion are concerned. But those are use-value considerations, and in capitalism monetary value is what matters. More precisely, what matters is not innovation per se, but the period of time high profits can be won from a competitive advantage due to innovation. From this standpoint the proliferation of effective national innovation systems presents a major problem for capitalism. As soon as an innovation showing promise of being exceptionally profitable is developed in one region of the world, national innovation systems across the global are mobilized more or less immediately, hoping to get a piece of the action. As a result, the time prior to the outbreak of the significant overproduction problems Hegel discussed necessarily tends to be significantly compressed, as well as the time high profits can be won from a competitive advantage from an innovation. 
In response, intellectual property rights have been extended in scope and enforcement, enabling a handful of firms to leverage publicly funded $\mathrm{R} \& \mathrm{D}$ into immense private gains. Waged work has become increasingly precarious, surveilled, and intensified, with labor's share of GDP declining across the globe. Increasing amounts of credit have been created to stave off a global depression. More working households have fallen into deeper debt. More credit has funded purchases of financial assets, generating financial bubbles and financial crises. Political irrationalities have proliferated as cynical and opportunistic political leaders (mis)direct blame and fear to the marginalized "other." Geopolitical dangers have escalated as powerful states see militarization as a way to prop up favored capitals and shift the costs of a stagnant world economy to other regions (Smith 2017).

Our consciousness lags behind this new historical situation. We still think a new "golden age" would be possible if only the right sort of public policies could be put in place. No more "golden ages" of capitalist development are likely. Capitalism has reached its historical limits not because there is too little innovation, but because there is too much, creating problems for a profit-driven system. To think that a social state could tame the pathologies of capitalism in these circumstances is to hold fast to an abstract ought, analogous to holding that the pathologies of slavery or feudalism ought to be overcome even as those social forms remain in place.

\section{Conclusion}

Hegel's commitment to substantial freedom was deep and unequivocal, as was his insistence that individual freedom for social beings like us can only be fulfilled in a free society:

The right of individuals to be subjectively determined as free is fulfilled when they belong to an actual ethical order, because their certainty of their freedom finds its truth in such an objective order, and it is in an ethical order that they are actually in possession of their own essence or their own inner universality (Hegel 2008, p. 160/§153).

Marx echoes Hegel's deep commitment to freedom when he calls for a society in which "the full and free development of every individual forms the ruling principle" (Marx 1976, p. 739). And he echoes the Hegelian claim that individual freedom for social beings can only be adequately found in a free social order when he asserts that "the free development of each is the condition for the free development of all" (Marx and Engels 
1976, p. 506). If there is a profound disagreement between Hegel and Marx, it does not primarily lie on the level of normative principles. It lies in the fact that Marx recognized the sense in which capital is the dominant "subject" and "self-moving substance" of our era, and Hegel did not.

If we could imagine that Hegel somehow did have an adequate concept of capital, we can confidently predict he would have criticized it as vehemently as he rejected other forms of abstract universality that have dominated human societies in the course of history. He would have acknowledged that a political order where the insane imperative "M must become M'!' has objective priority over the political community necessarily rules out a social order where universality, particularity, and individuality are objectively reconciled in the way expressed in the system of syllogisms summarized in the passage at the conclusion of section 1. To comprehend Marx's concept of capital is to comprehend why a capitalist market society cannot be a rational social order warranting rational affirmation, and why the modern capitalist state cannot be a "concrete universal."

Where do we go from here? There are places in Marx's early writings where he advocates creating a form of communism reduces the complex dialectic of society and individual to simple and unmediated relationships among individuals spontaneously co-operating in harmony. Hegel teaches us that such a lack of institutional mediation is quite impossible in a complex modern society. Any attempt to institute it would be dangerous as well, leading to chaos that would likely make an authoritarian rule promising to restore order an attractive option.

In his later discussion of the Paris Commune in "The Civil War in France," however, Marx assumes there will be recurrent and significant disagreements in a post-capitalist society, requiring mediation within institutionalized sites of democratic discussion and decision-making. $\mathrm{He}$ affirms that all mature individuals have a right to participate in decisions affecting them directly or indirectly, in both workplaces and local communities, including rights to freely present one's own particular views and the reasons behind them, and to examine critically the views of others. Since decisions made by communes in particular workplaces and local communities have repercussions on those elsewhere, Marx also endorses higher-order (more universal) deliberation and decision-making representative bodies, with all representatives elected, subject to recall, and paid only average workers' wages (Marx 1986b). 
Marx's very compressed sketch of radical deliberative democracy is undoubtedly inadequate as it stands. ${ }^{8}$ Nonetheless, it establishes that Marx shares Hegel's commitment to a strong civic republicanism, albeit with one important difference. Marx extends the scope of civic republicanism to all exercises of public power, including authority exercised in workplaces and in the allocation of the social surplus. The project of struggling for this democratic form of socialism can be defended on good Hegelian grounds: a democratic form of socialism would mediate universality, particularity, and individuality within a political community in the manner Hegel rightly saw as defining a rational social order. This cannot be said of any community subject to the abstract universal that is capital.

\section{References}

Hahnel, Robin and E.O. Wright (2016), Alternatives to Capitalism: Proposals for a Democratic Economy, London: Verso.

Hegel, G.W.F. (1975) [1830], Logic: Part One of the Encyclopaedia of the Philosophical Sciences, London: Oxford University Press.

Hegel, G.W.F. (2008) [1820], Outlines of the Philosophy of Right, New York: Oxford University Press.

Kalecki, Michał (1971) [1943], 'Political Aspects of Full Employment', in Selected Essays on the Dynamics of the Capitalist Economy, Cambridge: Cambridge University Press.

Marx, Karl (1976) [1867], Capital, Volume I, New York: Penguin.

Marx, Karl (1986a) [1939], "Outlines of the Critique of Political Economy" [Grundrisse], in Marx and Engels Collected Works Volume 28, New York: International Publishers.

Marx, Karl (1986b) [1871], 'The Civil War in France', in Marx and Engels Collected Works, Volume 22, New York: International Publishers.

Marx, Karl and Frederick Engels (1976) [1848], The Communist Manifesto. In Marx and Engels Collected Works Volume 6, New York: International Publishers.

R\&DMagazine, 2016, “2016 Global R\&D Funding Forecast..”Winter. https://www. iriweb.org/sites/default/files/2016GlobalR\%26DFundingForecast_2.pdf Retrieved April 26, 2019.

8 More robust models of democratic socialism are found in Schweickart 1993, 2011, Smith 2005: Chapter 8, 2017: Chapter 13, and Hahnel and Wright 2016. All retain the right to personal property and to the principle of particularity (freedom of choice in consumption, occupation, etc.) defended by Hegel. 
Schweickart, David (1993), Beyond Capitalism, Cambridge: Cambridge University Press.

Schweickart, David (2011), After Capitalism, second edition, Lanham, MD: Rowman \& Littlefield.

Smith, Tony (1990), The Logic of Marx's Capital: Replies to Hegelian Criticisms, Albany: SUNY Press.

Smith, Tony (2005), Globalisation: A Systematic Marxian Account, Leiden: Brill. Smith, Tony (2017), Beyond Liberal Egalitarianism, Leiden: Brill.

Vieweg, Klaus (2012), Das Denken der Freiheit: Hegels Grundlinien der Philosophie des Rechts, München: Wilhelm Fink.

Westphal, Kenneth R. (2018), Normative Justification, Natural Law \& Kant Constructivism in Hegel's Moral Philosophy, Leiden: Brill.

\begin{abstract}
Hegel conceptualized the capitalist economy as a system of needs, with commodities and money serving as means to human ends. While anticipating Marx's criticisms of certain tendencies in capitalism, Hegel insisted that higher-order institutions, especially those of the modern state, could put them out of play and establish a reconciliation of universality, particularity, and individuality warranting rational affirmation. Hegel, however, failed to comprehend the emergence of capital as a dominant subject, subordinating human ends under its end ("valorization"). The structural coercion, domination, and exploitation inherent in the capital/wage labor relationship illustrate that point, as does the depoliticization of inherently political matters in capitalist market societies. The reconciliation of universality, particularity, and individuality Hegel endorsed requires a form of socialism incorporating deliberative democracy in local workplaces and communities, conjoined with representative bodies on regional, national, and ultimately global levels.
\end{abstract}

Keywords: Value - Capital - Valorization - State - Socialism 


\section{RESUMO}

Hegel concebeu a economia capitalista como um sistema de necessidades, onde as mercadorias e o dinheiro servem de meio para a obtenção de fins humanos. Antecipando as críticas de Marx a algumas tendências do capitalismo, Hegel insistiu no facto de um conjunto instituições de ordem superior - especialmente as instituições do Estado moderno - poder contrariar essas tendências e levar a uma reconciliação racional entre o universal, o particular e o individual. Contudo, Hegel não compreendeu a emergência do capital como sujeito dominante, que subordina os fins humanos ao seu próprio fim ("valorização"). A coerção estrutural, a dominação e a exploração inerentes à relação capital/trabalho assalariado ilustram este ponto, bem como a despolitização, nas sociedades de mercado capitalistas, de elementos intrinsecamente políticos. A reconciliação entre o universal, o particular e o individual defendida por Hegel requer uma forma de socialismo que incorpore a democracia deliberativa nos locais de trabalho e nas comunidades locais, em articulação com corpos representativos de alcance regional, nacional e, em última instância, global.

Palavras-chave: Valor - Capital - Valorização - Estado - Socialismo 